\title{
In vitro study of postbiotics from Lactobacillus plantarum RG14 on rumen fermentation and microbial population
}

\author{
Wan Ibrahim Izuddin ${ }^{1}$ (D), Teck Chwen Loh" ${ }^{1,2^{*}}$ (D), Anjas Asmara Samsudin ${ }^{1,2}$ (D), Hooi Ling Foo ${ }^{3,4}$ (iD) \\ 1 Universiti Putra Malaysia, Faculty of Agriculture, Department of Animal Science, Serdang, Selangor, Malaysia. \\ 2 Universiti Putra Malaysia, Institute of Tropical Agriculture and Food Security, Serdang, Selangor, Malaysia. \\ 3 Universiti Putra Malaysia, Faculty of Biotechnology and Biomolecular Sciences, Department of Bioprocess Technology, Serdang, Selangor, \\ Malaysia. \\ ${ }^{4}$ Universiti Putra Malaysia, Institute of Bioscience, Serdang, Selangor, Malaysia.
}

\begin{abstract}
An in vitro study was carried out to identify the effects of different inclusion levels of postbiotics from Lactobacillus plantarum RG14 on rumen fermentation profiles, gas production kinetics, and microbial population in rumen fluid collected from goats. Postbiotics were added at different levels $(0,0.3,0.6,0.9$, and 1.2\%) and incubated for $72 \mathrm{~h}$ with $200 \mathrm{mg}$ dry matter (DM) of a substrate containing $60 \%$ Guinea grass and $40 \%$ commercial concentrate. The experiment was conducted in triplicate on different days with four replications per treatment. Rumen fermentation kinetics, $\mathrm{pH}$, organic matter digestibility (OMD), volatile fatty acids (VFA), and microbial populations were investigated. Net gas production and gas production from the immediate soluble fraction (a) increased linearly, and the volume of gas produced from the insoluble fraction (b) and potential gas production $(a+b)$ quadratically increased with the increasing levels of postbiotics. A significant linear increase in OMD was observed for increasing postbiotic levels. Total and individual molarity of ruminal VFA and acetic acid to propionic ratio were also significantly increased by postbiotic inclusion. Populations of total bacteria, cellulolytic bacteria (Fibrobacter succinogenes, Ruminococcus albus, Ruminococcus flavefaciens), and total protozoa were significantly increased in the postbiotic treatment. Postbiotics in the ruminal fluid in vitro enhance rumen fermentation and improve digestibility and VFA production without any adverse effects on $\mathrm{pH}$.
\end{abstract}

Key Words: feed additive, fermentation profile, Lactobacillus, ruminal kinetics, rumen microorganisms, volatile fatty acids

\section{Introduction}

The development of antibiotic-resistant bacteria due to the excessive use of antibiotics in animal production poses significant health risks to both livestock and humans (Van Boeckel et al., 2015). In ruminants, the use of antibiotics to manipulate the microbial ecosystem to improve fibrous feed use has been discouraged due to several disadvantages such as toxicity, potential allergies, and residues in livestock products (Ramaswami et al., 2005). Direct-fed microbials (DFM) or probiotics, which are defined as "a source of live naturally-occurring microorganisms", are currently being used as supplements for ruminants (Yoon and Stern, 1995). Lactic acid bacteria as probiotics have been used in ruminant diets to enhance the beneficial microflora population, which

Received: November 1, 2017

Accepted: May 1, 2018

*Corresponding author: tcloh@upm.edu.my

Copyright (C) 2018 Sociedade Brasileira de Zootecnia. This is an Open Access article distributed under the terms of the Creative Commons Attribution License (http://creativecommons.org/licenses/by/4.0/), which permits unrestricted use, distribution, and reproduction in any medium, provided the original work is properly cited. in turn will prevent pathogenic microbial establishment. They positively influence the microbial ecosystem by establishing native gastrointestinal microbes in young calves and by contributing to the equilibrium of microbial groups in the gastrointestinal system (Bae et al., 2003; Ramaswami et al., 2005). Although the beneficial effects of probiotics are undisputed, they could represent a threat to the host. Some probiotics have antibiotic resistance genes, particularly plasmid-encoded bacteria, which can be transferred between organisms (Marteau and Shanahan, 2003).

In this context, postbiotic produced from lactic acid bacteria contain no living cells and are a potential feed additive in livestock and poultry production (Thu et al., 2011a). Postbiotics contain intermediates and/or final products in metabolism of Lactobacillus sp., mainly lactic and acetic acid and antimicrobial peptides known as bacteriocins (Foo et al., 2005; Thanh et al., 2010; Thu et al., 2011a; Choe et al., 2013). Postbiotics exhibit probiotic effects that reduce the $\mathrm{pH}$ in the intestines, increase the lactic acid bacteria population, and decrease the Enterobacteriaceae population (Foo et al., 2005). They also improve growth performance, increase intestinal villus 
height, and decrease faecal Enterobacteriaceae counts in broilers (Loh et al., 2010), laying hens (Choe et al., 2012), and piglets (Thu et al., 2011b).

The use of postbiotics in monogastric farm animals is well established; however, information about the use of postbiotics in ruminant diets is limited. In ruminants, direct-fed microbes such as Lactobacilli have been used as feed additives in improving animal welfare and performance. The interaction of lactic acid bacteria with rumen microorganisms to enhance rumen fermentation and inhibition of harmful microorganisms due to the presence of antimicrobial substances such as bacteriocins are proposed by Weinberg et al. (2003) as the mode of action of lactic acid bacteria in the rumen. Lactic acid-producing bacteria produce a steady lactic acid in the rumen, assists the microflora to accustom with the lactic acid accumulation, enhance lactate-utilizing bacteria, and stabilize ruminal pH (Yoon and Stern, 1995; Seo et al., 2010; Retta, 2016). Similar effect could be achieved by supplementing postbiotics as a feed additive. We therefore evaluated the effects of postbiotics produced by Lactobacillus plantarum (L. plantarum) on rumen fermentation and microbial population in vitro.

\section{Material and Methods}

This study was conducted in Serdang, Selangor, Malaysia $\left(2^{\circ} 58^{\prime} 58^{\prime \prime} \mathrm{N}\right.$ and 101 $\left.44^{\prime} 06^{\prime \prime} \mathrm{E}\right)$, following guidelines of the university research policy.

The postbiotics were produced by Lactobacillus plantarum RG14. The stock culture was revived twice in de-Mann Rogosa Sharpe (MRS) broth by incubating at $30{ }^{\circ} \mathrm{C}$ for 48 and $24 \mathrm{~h}$, respectively. The streak plate was conducted on MRS agar and incubated for $48 \mathrm{~h}$ at $30{ }^{\circ} \mathrm{C}$; subsequently, a single colony was picked and incubated in MRS broth for $48 \mathrm{~h}$. The colony was then subcultured in MRS broth, incubated for $24 \mathrm{~h}$ at $30^{\circ} \mathrm{C}$, and used as inoculum. One percent of the culture was inoculated into reconstituted media and incubated for $24 \mathrm{~h}$ at $30^{\circ} \mathrm{C}$. Centrifugation was performed at $10,000 \times g$ to separate bacterial cells, and the postbiotics were harvested by collecting the supernatant. The collected postbiotics were examined for inhibitory activity by conducting an agar well diffusion assay, using Pediococcus acidilactici as the indicator organism.

Two male goats ( $30 \pm 2 \mathrm{~kg}$ body weight), fitted with a permanent rumen cannula, were housed individually in raised floor pens. Fresh water and mineral blocks were provided ad libitum. The goats were maintained on a daily diet containing $60 \%$ dry matter (DM) fresh Guinea grass (Panicum maximum) with $40 \%$ DM commercial concentrate and fed twice daily at 08:00 and 17:00 h. Rumen fluid was taken in the morning before feeding and transferred immediately into pre-warmed $\left(39{ }^{\circ} \mathrm{C}\right)$ insulated vacuum flasks to ensure anaerobic conditions. In the laboratory, rumen fluid was continuously flushed with $\mathrm{CO}_{2}$ to maintain the anaerobic condition. The collected rumen fluids samples were pooled, filtered through four layers of cheesecloth into a pre-warmed conical flask bath, mixed with buffer at the ratio of $1: 2$, and kept at $39{ }^{\circ} \mathrm{C}$ in a water bath prior to transfer to fermentation syringes. The buffer solution was prepared according to Menke and Steingass (1988).

In vitro gas production was evaluated according to Menke and Steingass (1988). Guinea grass and commercial concentrate were used as a substrate and ground to pass through a $1.0-\mathrm{mm}$ sieve. The combination of Guinea grass and commercial concentrate were used as the substrate for in vitro rumen fermentation (Table 1). The substrate was weighed to $0.2 \pm 0.0001 \mathrm{~g} \mathrm{DM}$ to contain $0.12 \mathrm{~g}$ of DM of Guinea grass and $0.08 \mathrm{~g}$ of DM of concentrate and dispensed into $100-\mathrm{mL}$ calibrated glass syringes fitted with pistons. Approximately $0.2 \pm 0.0001 \mathrm{~g} \mathrm{DM}$ of standard hay and standard concentrate (University of Hohenheim, Stuttgart, Germany) with known gas production were also used for incubation (Menke and Steingass, 1988). Subsequently, $30 \mathrm{~mL}$ of buffered rumen fluid were dispensed into syringes containing substrate with different levels of postbiotics, syringes with postbiotics without substrate, syringes containing hay and concentrate standards, and blank syringes without substrate. Postbiotic inclusion levels were 0 (control), $0.3,0.6,0.9$, and $1.2 \%$, based on the rumen fluid media. The syringes were incubated in a water bath at a constant temperature of $39 \pm 0.1{ }^{\circ} \mathrm{C}$. Gas production was recorded at $3,6,12,24,48$, and $72 \mathrm{~h}$ of incubation. The in vitro experiment was conducted in three runs on separate days, with four replications per treatment.

At the end of the incubation, the $\mathrm{pH}$ of the rumen fluid was measured immediately using a $\mathrm{pH}$ meter (MettlerToledo Ltd., England, UK). An aliquot of $2 \mathrm{~mL}$ of the rumen

Table 1 - Chemical composition ( $\left.\mathrm{g} \mathrm{kg}^{-1} \mathrm{DM}\right)$ of Guinea grass and commercial concentrate

\begin{tabular}{lccc}
\hline & Guinea grass & Concentrate $^{1}$ & Combination $^{2}$ \\
\hline Chemical composition $\left(\mathrm{g} \mathrm{kg}^{-1} \mathrm{DM}\right)$ & & \\
Dry matter (DM) & 924.34 & 867.73 & 906.32 \\
Ash & 110.50 & 70.50 & 95.33 \\
Crude protein & 115.40 & 122.10 & 118.80 \\
Ether extract & 47.68 & 25.50 & 29.18 \\
Neutral detergent fibre & 771.33 & 385.67 & 729.33 \\
Acid detergent fibre & 478.33 & 191.67 & 358.67 \\
Lignin & 266.00 & 91.67 & 201.33 \\
\hline${ }^{1}$ Commercial goat concentrate. & & \\
${ }^{2}$ Combination of $60 \%$ Guinea grass and $40 \%$ commercial concentrate
\end{tabular}

R. Bras. Zootec., 47:e20170255, 2018 
fluid was collected for microbial population determination and another $10 \mathrm{~mL}$ of the fluid were taken for volatile fatty acids (VFA) analysis. The sample was then kept in a freezer at $-20{ }^{\circ} \mathrm{C}$ until analysis. The VFA of the rumen fluid were determined using a 6890N Network GC System gas chromatograph (Agilent Technologies) according to Filípek and Dvořák (2009). The rumen fluid was acidified with $25 \%$ metaphosphoric acid in the ratio of $4: 1(\mathrm{v} / \mathrm{v})$ and centrifuged at $3,000 \times g$ for $10 \mathrm{~min}$. The supernatant was collected, filtered, and used for VFA determination. As internal standard, 4-methyl-n-valeric acid (Sigma, St. Louis, MO) was used.

Quantification of the microbial population in the rumen fluid was performed after $72 \mathrm{~h}$ of incubation. Extraction of DNA from the ruminal fluid was carried out using the QIAamp ${ }^{\circledR}$ Fast DNA Stool Mini Kit (Qiagen, Hilden, Germany), following the manufacturer's protocol. The concentration of the extracted DNA was quantified using a Nanodrop 2000 spectrophotometer (Thermo Scientific, Wilmington. DE). The populations of total bacteria, $L$. plantarum, Ruminococcus albus (R. albus), Ruminococcus flavefaciens (R. flavefaciens), Fibrobacter succinogenes (F. succinogenes), and protozoa were analysed by using qPCR. Absolute quantification of microbes in the rumen fluid was performed based on the standard curve of amplification of target microbes. Approximately $20 \mu \mathrm{L}$ of qPCR master mix were prepared for each reaction, using the QuantiNova ${ }^{\mathrm{TM}}$ SYBR Green PCR kit (Qiagen, Hilden, Germany), which consists of $10 \mu \mathrm{L}$ of $2 \mathrm{X}$ SYBR Green Master Mix, $1 \mu \mathrm{L}$ of $14 \mu \mathrm{M}$ forward primer, $1 \mu \mathrm{L}$ of $14 \mu \mathrm{M}$ reverse primer, $2 \mu \mathrm{L}$ of DNA samples, and $6 \mu \mathrm{L}$ of RNase-free water. Real-time qPCR (Table 2) was performed with the Bio-Rad CFX96 Real-time PCR system (Bio-Rad Laboratories, Hercules, CA), using optical grade plates. The qPCR cycling conditions consisted of an initial heat activation at $95{ }^{\circ} \mathrm{C}$ for
2 min, followed by 40 cycles of denaturation at $95{ }^{\circ} \mathrm{C}$ for $5 \mathrm{~s}$ and a combined annealing and extension temperature, depending on the target microbes. Melting curve analysis was performed at the end of the amplification cycle to confirm the specificity of amplification.

Standard hay and standard concentrate (University of Hohenheim, Stuttgart, Germany), with an average gas production of 49.61 and $61.13 \mathrm{~mL}$, respectively, were used for calibration. Blank (buffered ruminal fluid only) and postbiotics only (buffered rumen fluid and postbiotics) were used to correct the gas production in the fermentation of the substrate by estimating gas production based on rumen fluid and postbiotics. A blank was also used to estimate the DM in the rumen fluid and to correct the DM degradation of the substrate. Gas production data were fitted into the model as described by Ørskov and McDonald, (1979): $\mathrm{Y}=\mathrm{a}+\mathrm{b}\left(1-\mathrm{e}^{-\mathrm{ct}}\right)$, in which $\mathrm{Y}=$ volume of gas produced at time $\mathrm{t}(\mathrm{mL}), \mathrm{a}=$ volume of gas produced from the immediately soluble fraction $(\mathrm{mL}), \mathrm{c}=$ gas production rate constant from the insoluble fraction $(\mathrm{mL} / \mathrm{h})$, and $\mathrm{t}=$ incubation time. Organic matter digestibility (OMD) of the substrate was determined following the equation of Menke et al. (1979): OMD (\%) $=14.88+0.889 \mathrm{GP}+$ $0.45 \mathrm{CP}+0: 0651 \mathrm{AC}$, in which $\mathrm{GP}=$ net gas produced at $24 \mathrm{~h}$ $(\mathrm{mL} / 200 \mathrm{mg})$ of incubation, $\mathrm{CP}=$ percentage of crude protein content, and $\mathrm{AC}=$ percentage of ash content of the substrate.

The experiment was conducted as a completely randomized design according to the following statistical model:

$$
\mathrm{Y}_{\mathrm{ij}}=\mu+\alpha_{\mathrm{i}}+\varepsilon_{\mathrm{ij}}
$$

in which, $\mathrm{Y}_{\mathrm{ij}}=$ observation of the effect of different postbiotic levels, $\mu=$ overall mean of the observation, $\alpha_{i}=$ effect of different levels of postbiotic ( $i=0,0.3,0.6,0.9$, $1.2)$ in in vitro rumen fermentation, and $\varepsilon_{\mathrm{ij}}=$ random error.

Table 2 - Sequence of polymerase chain reaction primers used to target total bacteria, L. plantarum, F. succinogenes, $R$. albus, R. flavefaciens, and total protozoa

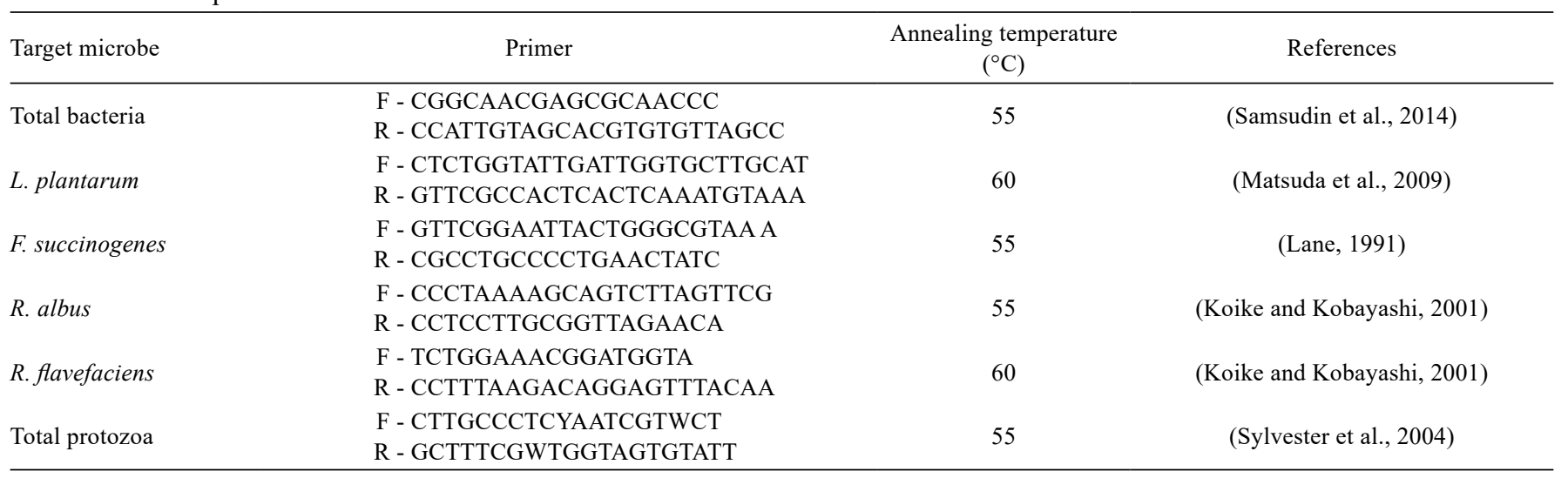

F - forward; R - reverse. 
The data were subjected to one-way ANOVA, using the General Linear Model (GLM) of the software package SAS (Statistical Analysis System, version 9.2). Duncan's Multiple Range Test was used to identify significant differences between the treatments. Orthogonal polynomial contrasts were used to determine the linear and quadratic effects of increasing postbiotic levels. Differences between treatment means were considered significant at $\mathrm{P}<0.05$.

\section{Results}

A significant linear increase $(\mathrm{P}<0.05)$ in net gas production at all incubation times was observed for increasing postbiotic levels (Table 3). Gas production from the fermentation of the insoluble fraction (b) and potential extent of the gas production $(\mathrm{a}+\mathrm{b})$ significantly differed between the different inclusion levels and the control. Gas production from the fermentation of the soluble fraction (a) was significantly higher $(\mathrm{P}<0.05)$, starting at $0.6 \%$ of postbiotic inclusion compared with the control. The OMD also showed a significant linear increase $(\mathrm{P}<0.05)$ with increasing inclusion levels

The $\mathrm{pH}$ was not affected $(\mathrm{P}>0.05)$ by the inclusion of postbiotics. In contrast, acetic, propionic, butyric, and total VFA linearly increased $(\mathrm{P}<0.05)$ with increasing inclusion levels (Table 4 ). The propionic acid and total VFA significantly different $(\mathrm{P}<0.05)$ at all inclusion levels of postbiotics. The ratio of acetic to propionic acid was not affected $(\mathrm{P}>0.05)$.

A significant quadratic increase (quadratic; $\mathrm{P}<0.05$ ) was observed in the total bacteria population during incubation with the addition of postbiotics (Table 5). However, the L. plantarum population was not affected $(\mathrm{P}<0.05)$ by the different inclusion levels. Interestingly, the populations of three major fibrolytic bacteria, namely $F$. succinogenes, $R$. albus, and $R$. flavefaciens, linearly increased $(\mathrm{P}<0.05)$ with increasing inclusion levels. A significant quadratic increase (quadratic; $\mathrm{P}<0.05$ ) in total protozoa was observed, starting from a postbiotic level of $0.6 \%$.

Table 3 - Effect of different levels of postbiotic inclusion on gas production at $72 \mathrm{~h}$ of in vitro incubation

\begin{tabular}{|c|c|c|c|c|c|c|c|c|}
\hline \multirow{2}{*}{ Parameter } & \multicolumn{5}{|c|}{ Level of postbiotic inclusion (\%) } & \multirow{2}{*}{ SEM } & \multicolumn{2}{|c|}{ Contrast, P-values } \\
\hline & 0 (control) & 0.3 & 0.6 & 0.9 & 1.2 & & Linear & Quadratic \\
\hline \multicolumn{9}{|c|}{$\begin{array}{l}\text { Net gas production }(\mathrm{mL} / 200 \mathrm{mg} \mathrm{DM}) \\
\text { Incubation time }(\mathrm{h})\end{array}$} \\
\hline 6 & $14.00 \mathrm{~d}$ & $15.00 \mathrm{c}$ & $16.80 \mathrm{~b}$ & $17.80 \mathrm{a}$ & $17.90 \mathrm{a}$ & 0.24 & $<0.0001$ & 0.0045 \\
\hline 12 & $25.50 \mathrm{c}$ & $26.40 \mathrm{cb}$ & $27.80 \mathrm{ab}$ & $28.70 \mathrm{a}$ & $29.20 \mathrm{a}$ & 0.49 & $<0.0001$ & 0.4294 \\
\hline 72 & $79.10 \mathrm{~b}$ & $82.30 \mathrm{a}$ & $83.00 \mathrm{a}$ & $84.10 \mathrm{a}$ & $84.30 \mathrm{a}$ & 0.62 & $<0.0001$ & 0.0143 \\
\hline \multicolumn{9}{|c|}{ Gas production parameter } \\
\hline $\mathrm{a}(\mathrm{mL})$ & $-6.06 c$ & $-5.54 \mathrm{c}$ & $-4.38 b$ & $-3.16 \mathrm{a}$ & $-3.68 \mathrm{a}$ & 0.30 & $<0.0001$ & 0.1976 \\
\hline $\mathrm{b}(\mathrm{mL})$ & $96.90 \mathrm{~b}$ & $99.00 \mathrm{a}$ & $100.00 \mathrm{a}$ & $100.70 \mathrm{a}$ & $99.00 \mathrm{a}$ & 0.63 & 0.0035 & 0.0091 \\
\hline $\mathrm{c}(\mathrm{mL} / \mathrm{h})$ & 0.03 & 0.03 & 0.03 & 0.03 & 0.03 & 0.00 & 0.4392 & 0.4151 \\
\hline$a+b$ & $91.00 \mathrm{c}$ & $93.50 \mathrm{~b}$ & $95.50 \mathrm{ab}$ & $97.50 \mathrm{a}$ & $96.00 \mathrm{a}$ & 0.59 & $<0.0001$ & 0.0062 \\
\hline
\end{tabular}

$\mathrm{a}$ - volume of gas produced from immediate soluble fraction; $\mathrm{b}$ - volume of gas produced from insoluble fraction; $\mathrm{c}$ - gas production rate constant from insoluble fraction; $\mathrm{a}+\mathrm{b}$ potential extent of gas production; OMD - organic matter digestibility; DM - dry matter; SEM - standard error of the mean.

a-d - Different letters in each row are significantly different $(\mathrm{P}<0.05)$.

Table 4 - Effect of different levels of postbiotic inclusion on $\mathrm{pH}$ and volatile fatty acids (VFA) at $72 \mathrm{~h}$ of in vitro incubation

\begin{tabular}{|c|c|c|c|c|c|c|c|c|}
\hline \multirow{2}{*}{ Parameter } & \multicolumn{5}{|c|}{ Level of postbiotic inclusion (\%) } & \multirow{2}{*}{ SEM } & \multicolumn{2}{|c|}{ Contrast, P-values } \\
\hline & 0 (control) & 0.3 & 0.6 & 0.9 & 1.2 & & Linear & Quadratic \\
\hline $\mathrm{pH}$ & 6.76 & 6.76 & 6.64 & 6.76 & 6.77 & 0.05 & 0.9064 & 0.1378 \\
\hline Acetic (mol/100 mol) & $29.20 b$ & $29.91 b$ & $31.77 \mathrm{a}$ & $32.71 \mathrm{a}$ & $32.79 a$ & 0.61 & $<0.0001$ & 0.1531 \\
\hline Propionic (mol/100 mol) & $9.00 \mathrm{c}$ & $9.92 b$ & $10.17 \mathrm{ba}$ & $10.84 \mathrm{a}$ & $10.88 \mathrm{a}$ & 0.46 & $<0.0001$ & 0.1424 \\
\hline Butyric (mol/100 mol) & $4.03 b$ & $4.32 b$ & $4.28 \mathrm{~b}$ & $4.94 a$ & $5.13 \mathrm{a}$ & 0.26 & $<0.0001$ & 0.4040 \\
\hline Total VFA (mM/L) & $42.23 \mathrm{~d}$ & $44.15 \mathrm{c}$ & $46.22 b$ & $48.49 \mathrm{a}$ & $48.8 \mathrm{a}$ & 0.81 & $<0.0001$ & 0.1003 \\
\hline Acetic/propionic ratio & 3.01 & 3.02 & 3.03 & 3.16 & 3.25 & 0.15 & 0.1001 & 0.6100 \\
\hline
\end{tabular}

SEM - standard error of the mean.

a-d - Different letters in each row are significantly different $(\mathrm{P}<0.05)$. 
Table 5 - Effect of different levels of postbiotic inclusion on the population of bacteria and total protozoa at $72 \mathrm{~h}$ in vitro incubation

\begin{tabular}{|c|c|c|c|c|c|c|c|c|}
\hline \multirow{2}{*}{$\log _{10} \operatorname{microbial} / \mathrm{mL}$} & \multicolumn{5}{|c|}{ Level of postbiotic inclusion (\%) } & \multirow{2}{*}{ SEM } & \multicolumn{2}{|c|}{ Contrast, P-values } \\
\hline & 0 (control) & 0.3 & 0.6 & 0.9 & 1.2 & & Linear & Quadratic \\
\hline Total bacteria & $8.90 \mathrm{c}$ & $9.22 b$ & $9.38 \mathrm{ab}$ & $9.46 \mathrm{a}$ & $9.49 \mathrm{a}$ & 0.07 & $<0.0001$ & 0.0172 \\
\hline L. plantarum & 2.45 & 2.43 & 2.39 & 2.15 & 2.68 & 0.14 & 0.7642 & 0.2250 \\
\hline F. succinogenes & $4.68 b$ & $4.94 \mathrm{ab}$ & $5.09 \mathrm{a}$ & $5.05 \mathrm{a}$ & $5.26 \mathrm{a}$ & 0.09 & 0.0010 & 0.4581 \\
\hline R. albus & $6.99 \mathrm{~b}$ & $7.48 \mathrm{a}$ & $7.52 \mathrm{a}$ & $7.62 \mathrm{a}$ & $7.74 \mathrm{a}$ & 0.09 & $<0.0001$ & 0.0886 \\
\hline R. flavefaciens & $2.44 b$ & $2.73 \mathrm{ab}$ & $3.25 \mathrm{a}$ & $3.16 \mathrm{a}$ & $2.84 \mathrm{ab}$ & 0.15 & 0.0306 & 0.0072 \\
\hline
\end{tabular}

SEM - standard error of the mean.

a-c - Different letters in each row are significantly different $(\mathrm{P}<0.05)$.

\section{Discussion}

In vitro gas production and in vivo feed digestibility are closely associated, with gas production being the result of the fermentation of nutrients in the feed. Previous studies have reported the ability of lactic acid bacteria to survive in the rumen, change the parameters of in vitro rumen fermentation, and affect rumen microflora (Gollop et al., 2005; Weinberg et al., 2004). Our results indicate that the addition of postbiotics enhanced rumen fermentation rates by increasing the gas production, rumen fermentation kinetics, and OMD. The measurement of in vitro gas production provides useful information on the digestion kinetics of soluble and insoluble fractions of feeds (Getachew et al., 1998). The negative gas production from the soluble fraction was due to delayed fermentation because of a delay in microbial colonization or a lag period after the degradation of the soluble fraction prior to cell wall fermentation (Blümmel and Becker, 1997). Increase in net gas production, volume of gas produced from insoluble fraction, and potential extent of gas production indicate an increase in the digestibility of substrates and activity of fibre-degrading microbes. Soriano et al. (2014) reported that $1 \%$ of the supernatant from Lactobacillus mucosae showed no significant difference in total gas production, gas production kinetics, and OMD. The different strains of lactic acid bacteria and the varying inclusion levels may have different impacts on rumen fermentation. The role of rumen microorganisms, including bacteria and protozoa, in the digestion of soluble and insoluble feed fractions is well known. In the present study, the improvement of gas production kinetics, OMD, and VFA due to postbiotic inclusion can be explained by the improvement in the major microbial population.

In the present study, the addition of postbiotics had no impact on $\mathrm{pH}$ levels, but significantly increased total and individual VFA production in the rumen fluid. Acetic to propionic ratio also increased with increasing inclusion levels of postbiotics. The fibrous component of plants is the major source of carbohydrates in ruminants which is fermented by the rumen microbes to produce VFA, which are then absorbed by the rumen wall, contributing a major energy source for the host animals (Candyrine et al. 2017). Nutrient components of the in vitro substrate are fermented, resulting in the production of VFA and gases (mainly $\mathrm{CO}_{2}$ and $\mathrm{CH}_{4}$ ) and microbial cell growth (Getachew et al., 1998). The improvement in substrate digestion by adding postbiotics contributed to the higher production of VFA. This finding is consistent with Soriano et al. (2014), who reported a significant improvement of individual and total VFA concentrations by the inclusion of $1 \%$ of the supernatant of L. mucosae in in vitro incubation over a period of $48 \mathrm{~h}$. In contrast, O'Brien et al. (2013) found that $5 \%(\mathrm{v} / \mathrm{v})$ of the supernatant of $L$. plantarum TUA1490L reduced the individual and total VFA levels; the authors suggested that this was due to the presence of high concentrations of hydrogen peroxide in the supernatant. The discrepancy of these findings may be due to the differences in the bacterial strains used and the different supernatant inclusion levels. In addition, the postbiotic level of up to $1.2 \%$ in this study did not cause a significant reduction of VFA. O'Brien et al. (2013) claimed that high concentrations of hydrogen peroxide in the supernatant collected from an L. plantarum culture may contribute to lower VFA levels. However, hydrogen peroxide was not detected in postbiotics (Thanh et al., 2010; Thu et al., 2011a).

Our study also highlights the effect of postbiotics on the microbial population in the in vitro rumen fermentation. Inclusion of postbiotic increased total bacteria, cellulolytic bacteria, and total protozoa. The improvement in molar concentration of acetic acid and acetic to propionic acid ratio shows increase in the activity of cellulolytic bacteria in rumen fluid as the higher the activity of cellulolytic bacteria, the higher the molarity of acetic acid produced. Fibrobacter, Ruminococcus, and Butyrivibrio are the dominant cellulolytic bacteria in the rumen that degrade fibre of plant cell wall to produce VFA (Krause et al. 1999). Likewise, increase in the population of cellulolytic bacteria 
could explain the higher gas production, OMD, and VFA. It is suggested that postbiotics are capable of exhibiting probiotic effects without the presence of living cells (Loh et al., 2010; Thanh et al., 2010; Thu et al., 2011b). The mechanism of lactic acid bacteria in modulating rumen microbes is still unclear. In the current study, the improvement in total bacteria and cellulolytic bacteria could be due to the interaction of postbiotics which contains metabolites of lactic acid bacteria with the rumen microbes. Weinberg et al. (2003) proposed the interaction of lactic acid bacteria with rumen microorganisms to enhance rumen fermentation and inhibition of harmful microorganisms due to the presence of antimicrobial substances such as bacteriocins by lactic acid bacteria. Yoon and Stern (1995) reported that the stimulation of microbial growth, changes in the fermentation pattern in the rumen, and improvement of the digestibility are the modes of action of probiotics supplemented in ruminant diets. Probiotic supplementation has been suggested to enhance the adaptation of ruminal microbes to the presence of lactic acid or to impede the lactic acid accumulation in the rumen by lactic acid degradation to acetic acid (Ghorbani et al., 2002; Nocek et al., 2002). Jiao et al. (2017) proposed that these conditions favour the activities of cellulolytic bacteria and increase microbial digestion of fibrous feeds. This is consistent with the current study, in which the increment of total bacteria and fibre-degrading bacteria improved OMD levels when postbiotics were included.

Information on the effects of postbiotics on the rumen microbial population, including ruminal protozoa, is scarce. The role of protozoa in the rumen is still unclear, but one study reports that elimination of the protozoa (defaunation) increases the microbial protein supply and reduces methane production (Newbold et al., 1986). The increase in the number of protozoa in the current study could be due to the presence of lactate in the postbiotics; protozoa consume lactate more rapidly than bacteria, resulting in higher lactate levels in defaunated animals (Newbold et al., 1986; Williams and Coleman, 1997).

\section{Conclusions}

The inclusion of postbiotics positively affects in vitro rumen fermentation parameters. The populations of cellulolytic bacteria, such as $F$. succinogenes, $R$. albus, and $R$. flavefaciens and protozoa, increase with the treatment with postbiotics. This indicates a higher fibre digestion, which may contribute to increased rumen fermentation.

\section{Acknowledgments}

The authors wish to acknowledge the financial support (IPS Grant) received from Universiti Putra Malaysia.

\section{References}

Bae, J. S.; Byun, J. R. and Yoon, Y. H. 2003. In vivo antagonistic effect of Lactobacillus helveticus CU 631 against Salmonella enteritidis KU101 infection. Asian-Australasian Journal of Animal Science 16:430-434. https://doi.org/10.5713/ajas.2003.430

Blümmel, M. and Becker, K. 1997. The degradability characteristics of fifty-four roughages and roughage neutral-detergent fibres as described by in vitro gas production and their relationship to voluntary feed intake. British Journal of Nutrition 77:757-768. https://doi.org/10.1079/BJN19970073

Candyrine, S. C. L.; Jahromi, M. F.; Ebrahimi, M.; Liang, J. B.; Goh, Y. M. and Abdullah, N. 2017. In vitro rumen fermentation characteristics of goat and sheep supplemented with polyunsaturated fatty acids. Animal Production Science 57:16071612. https://doi.org/10.1071/AN15684

Choe, D. W.; Foo, H. L.; Loh, T. C.; Hair-Bejo, M. and Awis, Q. S. 2013. Inhibitory property of metabolite combinations produced from Lactobacillus plantarum strains. Pertanika Journal of Tropical Agricultural Science 36:79-88.

Choe, D. W.; Loh, T. C.; Foo, H. L.; Hair-Bejo, M. and Awis, Q. S. 2012. Egg production, faecal $\mathrm{pH}$ and microbial population, small intestine morphology, and plasma and yolk cholesterol in laying hens given liquid metabolites produced by Lactobacillus plantarum strains. British Poultry Science 53:106-115. https://doi.org/10.1080/00071668.2012.659653

Filípek, J. and Dvořák, R. 2009. Determination of the volatile fatty acid content in the rumen liquid: Comparison of gas chromatography and capillary isotachophoresis. Acta Veterinaria Brno 78:627-633. https://doi.org/10.2754/avb200978040627

Foo, H. L.; Lim, Y. S.; Loh, T. C.; Saleh, N. M.; Raha, A. R. and Rusul, G. 2005. Characterization of bacteriocin produced by Lactobacillus plantarum I-UL4 isolated from malaysian fermented tapioca, tapai ubi. p.33. In: Proceeding of 4th NIZO Dairy Conference, Papendal, Netherland.

Getachew, G.; Blümmel, M.; Makkar, H. and Becker, K. 1998. In vitro gas measuring techniques for assessment of nutritional quality of feeds: a review. Animal Feed Science and Technology 72:261-281. https://doi.org/10.1016/S0377-8401(97)00189-2

Ghorbani, G.; Morgavi, D.; Beauchemin, K. and Leedle, J. 2002. Effects of bacterial direct-fed microbials on ruminal fermentation, blood variables, and the microbial populations of feedlot cattle. Journal of Animal Science 80:1977-1985.

Gollop, N.; Zakin, V. and Weinberg, Z. G. 2005. Antibacterial activity of lactic acid bacteria included in inoculants for silage and in silages treated with these inoculants. Journal of Applied Microbiology 98:662-666. https://doi.org/10.1111/j.1365-2672.2004.02504.x

Jiao, P. X.; Liu, F. Z.; Beauchemin, K. A. and Yang, W. Z. 2017. Impact of strain and dose of lactic acid bacteria on in vitro ruminal fermentation with varying media $\mathrm{pH}$ levels and feed substrates. Animal Feed Science and Technology 224:1-13. https://doi. org/10.1016/j.anifeedsci.2016.11.005

Koike, S. and Kobayashi, Y. 2001. Development and use of competitive PCR assays for the rumen cellulolytic bacteria: Fibrobacter succinogenes, Ruminococcus albus and Ruminococcus flavefaciens. FEMS Microbiology Letters 204:361-366. https://doi.org/10.1016/S0378-1097(01)00428-1 
Krause, D. O.; McSweeney, C. S. and Forster, R. J. 1999. Molecular ecological methods to study fibrolyticruminal bacteria: phylogeny, competition and persistence. p.15-19. In: Proceedings of the 8th International Symposium on Microbial Ecology.

Lane, D. 1991. 16s/23s rRNA sequencing. p.115-175. In: Nucleic acid techniques in bacterial systematic. Stackebrandt, E. and Goodfellow, M., eds. John Wiley and Sons, New York.

Loh, T. C.; Thanh, N. T.; Foo, H. L.; Hair-Bejo, M. and Azhar, B. K. 2010. Feeding of different levels of metabolite combinations produced by Lactobacillus plantarum on growth performance, fecal microflora, volatile fatty acids and villi height in broilers. Animal Science Journal 81:205-214. https://doi.org/10.1111/ j.1740-0929.2009.00701.x

Marteau, P. and Shanahan, F. 2003. Basic aspects and pharmacology of probiotics: An overview of pharmacokinetics, mechanisms of action and side-effects. Best Practice and Research: Clinical Gastroenterology 17:725-740. https://doi.org/10.1016/S15216918(03)00055-6

Matsuda, K.; Tsuji, H.; Asahara, T.; Matsumoto, K.; Takada, T. and Nomoto, K. 2009. Establishment of an analytical system for the human fecal microbiota, based on reverse transcription-quantitative PCR targeting of multicopy rRNA molecules. Applied and Environmental Microbiology 75:1961-1969. https://doi.org/10.1128/AEM.01843-08

Menke, K. H.; Raab, L.; Salewski, A.; Steingass, H.; Fritz, D. and Schneider, W. 1979. The estimation of the digestibility and metabolizable energy content of ruminant feedingstuffs from the gas production when they are incubated with rumen liquor in vitro. Journal of Agricultural Science 93:217-222. https://doi. org/10.1017/S0021859600086305

Menke, K. H. and Steingass, H. 1988. Estimation of the energetic feed value obtained from chemical analysis and in vitro gas production using rumen fluid. Animal Research and Development 28:7-55.

Newbold, C. J.; Chamberlain, D. G. and Williams, A. G. 1986. The effects of defaunation on the metabolism of lactic acid in the rumen. Journal of the Science of Food and Agriculture 37:10831090. https://doi.org/10.1002/jsfa.2740371105

Nocek, J. E.; Kautz, W. P.; Leedle, J. A. Z. and Allman, J. G. 2002. Ruminal supplementation of direct-fed microbials on diurnal $\mathrm{pH}$ variation and in situ digestion in dairy cattle. Journal of Dairy Science 85:29-433. https://doi.org/10.3168/jds.S00220302(02)74091-5

O'Brien, M.; Hashimoto, T.; Senda, A.; Nishida, T. and Takahashi, J. 2013. The impact of Lactobacillus plantarum TUA1490L supernatant on in vitro rumen methanogenesis and fermentation. Anaerobe 22:137-140. https://doi.org/10.1016/j. anaerobe.2013.06.003

Ørskov, E. R. and McDonald, I. 1979. The estimation of protein degradability in the rumen from incubation measurements weighted according to rate of passage. Journal of Agricultural Science 92:499-503. https://doi.org/10.1017/S0021859600063048

Ramaswami, N.; Chaudhary, L. C.; Agarwal, N. and Kamra, D. N. 2005. Effect of lactic acid producing bacteria on the performance of male crossbred calves fed roughage based diet. Asian-Australasian Journal of Animal Science 18:1110. https://doi.org/10.5713/ajas.2005.1110
Retta, K. S. 2016. Role of probiotics in rumen fermentation and animal performance: a review. International Journal of Livestock Production 7:24-32. https://doi.org/10.5897/IJLP2016.0285

Samsudin, A. A.; Wright, A. D. and Al Jassim, R. 2014. The effect of fibre source on the numbers of some fibre-degrading bacteria of Arabian camel's (Camelus dromedarius) foregut origin. Tropical Animal Health and Production 46:1161-1166. https://doi. org/10.1007/s11250-014-0621-6

Soriano, A. P.; Mamuad, L. L.; Kim, S.-H.; Choi, Y. J.; Jeong, C. D.; Bae, G. S.; Chang, M. B. and Lee, S. S. 2014. Effect of Lactobacillus mucosae on in vitro rumen fermentation characteristics of dried brewers grain, methane production and bacterial diversity. Asian-Australasian Journal of Animal Science 27:1562-1570. https://doi.org/10.5713/ajas.2014.14517

Seo, J. K.; Kim, S. W.; Kim, M. H.; Upadhaya, S. D.; Kam, D. K. and Ha, J. K. 2010. Direct-fed microbials for ruminant animals. Asian-Australasian Journal of Animal Sciences 23:1657-1667. https://doi.org/10.5713/ajas.2010.r.08

Sylvester, J. T.; Karnati, S. K.; Yu, Z.; Morrison, M. and Firkins, J. L. 2004. Development of an assay to quantify rumen ciliate protozoal biomass in cows using Real-time PCR. The Journal of Nutrition 134:3378-3384. https://doi.org/10.1093/jn/134.12.3378

Thanh, N. T.; Chwen, L. T.; Foo, H. L.; Hair-Bejo, M. and Kasim, A. B. 2010. Inhibitory activity of metabolites produced by strains of Lactobacillus plantarum isolated from Malaysian fermented food. International Journal of Probiotics and Prebiotics 5:37.

Thu, T. V.; Foo, H. L.; Loh, T. C. and Bejo, M. H. $2011 \mathrm{a}$ Inhibitory activity and organic acid concentrations of metabolite combinations produced by various strains of Lactobacillus plantarum. African Journal of Biotechnology 10:1359-1363.

Thu, T. V.; Loh, T. C.; Foo, H. L.; Yaakub, H. and Bejo, M. H. 2011b. Effects of liquid metabolite combinations produced by Lactobacillus plantarum on growth performance, faeces characteristics, intestinal morphology and diarrhoea incidence in postweaning piglets. Tropical Animal Health and Production 43:69-75.

Van Boeckel, T. P.; Brower, C.; Gilbert, M.; Grenfell, B. T.; Levin, S. A.; Robinson, T. P.; Teillant, A. and Laxminarayan, R. 2015. Global trends in antimicrobial use in food animals. p.5649-5654. In: Proceedings of the National Academy of Sciences.

Weinberg, Z. G.; Chen, Y. and Gamburg, M. 2004. The passage of lactic acid bacteria from silage into rumen fluid, in vitro studies. Journal of Dairy Science 87:3386-3397. https://doi.org/10.3168/ jds.S0022-0302(04)73474-8

Weinberg, Z. G.; Muck, R. E. and Weimer, P. J. 2003. The survival of silage inoculant lactic acid bacteria in rumen fluid. Journal of Applied Microbiology 94:1066-1071.

Williams, A. G. and Coleman, G. S. 1997. The rumen protozoa. p.73-139. In: The rumen microbial ecosystem. Springer Science and Business Media.

Yoon, I. K. and Stern, M. D. 1995. Influence of direct-fed microbials on ruminal microbial fermentation and performance of ruminants: a review. Asian-Australasian Journal of Animal Sciences 8:533-555. https://doi.org/10.5713/ajas.1995.553 